\title{
Feasibility study of the project of using own-produced mayonnaise at a public catering enterprise
}

\author{
Natalia Bugaets ${ }^{1, *}$, Igor Tereshchenko ${ }^{1}$, Andrew Yakimenko $^{1}$, and Ivan Bugaets ${ }^{1}$ \\ ${ }^{1}$ Kuban State Technological University, 2, Moskovskaya St., Krasnodar, 350072, Russian Federation
}

\begin{abstract}
The relevance of the issue considered in the paper follows from the current state of development of public catering, when the recipe components of industrial production (sauces, seasonings, marinades, semi-finished products, etc.) are replaced by products produced at the enterprises of the food industry. The technology and formulations of fat and oil products of emulsion nature - mayonnaise, enriched with biologically active additives with high nutritional and functional properties have been developed. The paper substantiates an approach to the feasibility study for the production of mayonnaise for functional purpose using acid-soluble chitosan, protein concentrate from sesame seeds and $\beta$-carotene at public catering establishments. On the basis of production and financial plans, analysis of project risks, an assessment of the economic efficiency from the introduction and implementation of the developed technological solutions was made. The production plan includes the following structural elements: the volume of capital investments, the capacity of the enterprise, the program for the production and sale of products, wages, the cost of fixed assets, the cost of production and sales of products. The financial plan included the volume of project financing, calculations of taxes, cash receipts and payments.
\end{abstract}

\section{Introduction}

An analysis of the specific features of the Krasnodar region (geographical location, structure and dynamics of the regional economy, socio-demographic indicators, etc.) makes it possible to highlight the development of innovative activities as the key strategic priorities of the investment policy of the region, which can have a positive impact on the growth of its competitiveness.

The development of the innovation system of the region will increase the efficiency of the sector of fundamental and applied science in the field of introducing goods, services and technologies aimed at meeting the needs of the population.

Tasks catering economy - is the satisfaction of people's needs: quality and safety of products, functional and therapeutic and prophylactic food products [1].

Functional nutrition develops in the direction of enriching food products of regular consumption with functional ingredients (flavonoids, vitamins, dietary fiber, probiotics, prebiotics, synbiotics, minerals, etc.) $[2,3]$.

One of the promising areas is the creation of mayonnaise for functional purpose - the second most popular sauce in the world after soy, despite the trend of healthy eating.

In this regard, mayonnaise recipes have been developed using chitosan and protein products from sesame seeds. Chitosan is a functional ingredient that helps the body withstands environmental factors [4]. The composition, consisting of chitosan and protein products from sesame seeds, is included in the developed recipes as an emulsifier and stabilizer, and allows you to exclude egg products from the composition of mayonnaise [5].

To determine the economic efficiency of the production and sale of the developed mayonnaise in the conditions of our own production, economic indicators for a public catering enterprise were calculated using the example of a restaurant chain.

The purpose of the research is to develop recommendations for the technical and economic assessment of the results of the introduction of scientific developments in the conditions of public catering enterprises.

\section{Materials and methods}

The object of the research is the production of mayonnaise for functional purpose using acid-soluble high-molecular chitosan, protein concentrate from sesame seeds and $\beta$-carotene in a public catering facility. The work uses an analytical research method based on a systematic approach to the problem under study.

\footnotetext{
Corresponding author: kubanochka23@yandex.ru
} 


\section{Results and discussion}

\subsection{Justification of the volume of capital investments for the project. Capital investment structure}

New mayonnaises are produced according to traditional technology for public catering establishments in a cold shop.

To ensure the technological process, raw materials are needed, as well as table scales (for dosing prescription components), a planetary mixer (for emulsification), a production table (on which the mixer and scales are installed), a refrigerator (in which the recipe components are stored, and then the finished product), washing bath.

The project is supposed to be implemented on the basis of an already functioning public catering enterprise with a completed cold workshop, and therefore additional capital expenditures are not expected (table 1).

Table 1. An indicative list of equipment required for the introduction of new technology.

\begin{tabular}{|c|c|c|c|c|}
\hline No. & Cold workshop equipment & $\begin{array}{l}\text { Dimensi } \\
\text { ons, } \mathrm{mm}\end{array}$ & $\begin{array}{l}\text { Quanti } \\
\text { ty, } \\
\text { pcs. }\end{array}$ & $\begin{array}{l}\text { Purchase } \\
\text { price, rub }\end{array}$ \\
\hline 1 & $\begin{array}{l}\text { Waste bin with lid, } 110 \mathrm{Ll} \text {, } \\
\text { polypropylene }\end{array}$ & $\begin{array}{c}505 \times 525 \\
\times 800\end{array}$ & 1 & 14000 \\
\hline 2 & $\begin{array}{l}\text { Production table, without } \\
\text { side, with a bottom solid } \\
\text { shelf }\end{array}$ & $\begin{array}{c}1000 x \\
600 x 850\end{array}$ & 1 & 7800 \\
\hline 3 & $\begin{array}{l}\text { Wall-mounted washstand, } \\
\text { femur, complete with } \\
\text { mixer and siphon, stainless } \\
\text { steel }\end{array}$ & $\begin{array}{c}400 \times 400 \\
\times 235\end{array}$ & 1 & 12000 \\
\hline 4 & $\begin{array}{l}\text { Cutting board shelf, } 4 \text { pcs, } \\
\text { stainless steel }\end{array}$ & $\begin{array}{c}300 \times 400 \\
\times 300 \\
\end{array}$ & 1 & 4200 \\
\hline 5 & $\begin{array}{c}\text { Closed wall cabinet, } \\
\text { stainless steel }\end{array}$ & $\begin{array}{c}1400 x \\
400 x 600 \\
\end{array}$ & 2 & 12000 \\
\hline 6 & $\begin{array}{c}\text { Refrigerated table, } 3 \\
\text { doors, } 3 \text { drawers, with } \\
\text { side, stainless steel, } 290 \mathrm{~L} \text {, } \\
(0-10)^{\circ} \mathrm{C}\end{array}$ & $\begin{array}{c}1274 \mathrm{x} \\
700 \mathrm{x} \\
1000\end{array}$ & 1 & 87000 \\
\hline 7 & $\begin{array}{c}\text { Planetary mixer with a } \\
\text { bowl of } 5 \mathrm{~L}, 3 \text { attachments } \\
\text { (whisk, hook, shovel), } \\
\text { speed variator }\end{array}$ & $\begin{array}{c}284 \times 382 \\
x 424\end{array}$ & 1 & 15000 \\
\hline 8 & $\begin{array}{c}\text { Refrigerating cabinet, } \\
1400 \mathrm{~L},(-2-10)^{\circ} \mathrm{C}, \\
\text { stainless steel, single } \\
\text { chamber } \\
\end{array}$ & $\begin{array}{c}1500 x \\
795 x \\
2050\end{array}$ & 1 & 52000 \\
\hline 9 & $\begin{array}{l}\text { Wardrobe table with } \\
\text { sliding doors, with side, } \\
\text { stainless steel }\end{array}$ & $\begin{array}{c}1500 \mathrm{x} \\
700 \times 850\end{array}$ & 1 & 28000 \\
\hline 10 & $\begin{array}{c}\text { Wall-mounted bactericidal } \\
\text { irradiator (complete with } 2 \\
\text { PHILIPS lamps) }\end{array}$ & $\begin{array}{l}930 \mathrm{x} \\
60 \mathrm{x} 155\end{array}$ & 1 & 4000 \\
\hline
\end{tabular}

\subsection{Plant capacities for the project. Production and sales program}

The capacity for the production of mayonnaise is determined based on the existing level of demand for mayonnaise of a functioning enterprise. As an alternative to the revenue indicator within the framework of this feasibility study, there are the costs of acquiring a similar capacity (and need) for the volume of industrial mayonnaise at the prices in force at the time of writing the feasibility study.

The company's annual need for mayonnaise is 5960 $\mathrm{kg}$, the average purchase price for $1 \mathrm{~kg}$ is at the level of 122.9 rubles (table 2 ).

Table 2. Industrial program for the production of mayonnaise.

\begin{tabular}{|l|l|l|l|l|}
\hline No. & Indicators & \multicolumn{3}{|l|}{ Value of indicators } \\
\cline { 3 - 5 } & & $\begin{array}{l}2018 \\
\text { yr. }\end{array}$ & $2019 \mathrm{yr}$. & $2020 \mathrm{yr}$. \\
\hline \multirow{1}{*}{1.} & $\begin{array}{l}\text { Mayonnaise with chitosan and } \\
\text { protein concentrate }\end{array}$ & & & \\
\cline { 2 - 5 } & $\begin{array}{l}\text { the need for a restaurant chain } \\
\text { in mayonnaise, kg }\end{array}$ & 5960 & 5960 & 5960 \\
\hline $\begin{array}{l}\text { power utilization percentage, } \\
\%\end{array}$ & $100 \%$ & $100 \%$ & $100 \%$ \\
\hline $\begin{array}{l}\text { production volume in kind, kg } \\
\text { average purchase price of 1 kg } \\
\text { of industrial mayonnaise, rub. }\end{array}$ & 122.9 & 122.9 & 122.9 \\
\hline $\begin{array}{l}\text { acquisition costs (equivalent } \\
\text { of revenue), rub }\end{array}$ & 732210 & 732210 & 732210 \\
\cline { 2 - 5 } VAT, rub & 66565 & 66565 & 66565 \\
\hline 2. & $\begin{array}{l}\text { Acquisition costs (equivalent } \\
\text { of revenue) excluding VAT, } \\
\text { rub }\end{array}$ & 665646 & 665646 & 665646 \\
\hline
\end{tabular}

\subsection{Number of employees, labor costs.} Systems and forms of remuneration

This project does not imply additional hiring of an employee for the production of mayonnaise and, since the project is considered an incremental method, there will be no additional labor costs within the enterprise.

\subsection{The cost of fixed assets, the form of depreciation, the rate of depreciation}

Since the project is considered an incremental method, and the implementation of capital investments within the framework of it is not expected, the company does not have new depreciable property.

\subsection{Production and marketing costs, variable and fixed costs}

Variable costs - those costs, the value of which increases with the growth of production and sales and decreases with their decrease

Material costs within the framework of this project are formed by the costs of chitosan. In fact, the share of direct material costs in the structure of revenue excluding VAT is about $51 \%$, which will be taken as a basis for calculating the effectiveness of the proposed implementation project (table 3 ). 
Table 3. Calculation of material costs for the production of mayonnaise with chitosan.

\begin{tabular}{|c|c|c|c|}
\hline Product name & $\begin{array}{c}\text { Price, } \\
\text { rub }\end{array}$ & $\begin{array}{c}\text { Consumption } \\
\text { rate, kg }\end{array}$ & $\begin{array}{c}\text { Amount, } \\
\text { rub }\end{array}$ \\
\hline $\begin{array}{c}\text { Refined deodorized } \\
\text { sunflower oil }\end{array}$ & 50.00 & 0.720 & 36.00 \\
\hline Table mustard & 56.39 & 0.024 & 1.35 \\
\hline Eggs (yolks) & 60.00 & 0.023 & 1.38 \\
\hline Granulated sugar & 44.00 & 0.019 & 0.84 \\
\hline Edible table salt & 20.59 & 0.005 & 0.10 \\
\hline $\begin{array}{c}\text { Salt Apple cider } \\
\text { vinegar 1\% }\end{array}$ & 104.01 & 0.144 & 14.98 \\
\hline $\begin{array}{c}\text { Sesame Seed Protein } \\
\text { Concentrate }\end{array}$ & 360.00 & 0.023 & 8.28 \\
\hline Chitosan & 3190.00 & 0.008 & 25.52 \\
\hline $\begin{array}{c}\text { 2\% aqueous solution of } \\
\text { b-carotene, 20 ml }\end{array}$ & 215.00 & 0.0005 & 5.38 \\
\hline $\begin{array}{c}\text { Water } \\
\text { me total cost of a raw } \\
\text { material set per 1 kg, } \\
\text { rub }\end{array}$ & 2.00 & 0.057 & 0.11 \\
\hline
\end{tabular}

Table 4. Production and marketing costs.

\begin{tabular}{|c|c|c|c|c|}
\hline \multirow[t]{2}{*}{ No. } & \multirow[t]{2}{*}{ Indicator } & \multicolumn{3}{|c|}{ Indicator value, rub } \\
\hline & & 2018 yr. & 2019 yr. & $2020 \mathrm{yr}$. \\
\hline \multirow[t]{6}{*}{1.} & $\begin{array}{l}\text { Direct (variable) costs, } \\
\text { total }\end{array}$ & 498438 & 498438 & 498438 \\
\hline & including: & & & \\
\hline & direct material costs & 478469 & 478469 & 478469 \\
\hline & $\begin{array}{l}\text { labor costs for workers, } \\
\text { employees and engineers }\end{array}$ & 0 & 0 & 0 \\
\hline & insurance premiums & 0 & 0 & 0 \\
\hline & others & 19969 & 19969 & 19969 \\
\hline \multirow[t]{2}{*}{2.} & Total (fixed) costs, total & 0 & 0 & 0 \\
\hline & including: & & & \\
\hline \multirow[t]{4}{*}{2.1 . } & $\begin{array}{l}\text { General production costs } \\
\text { for the project, total }\end{array}$ & 0 & 0 & 0 \\
\hline & including: & & & \\
\hline & depreciation deductions & 0 & 0 & 0 \\
\hline & $\begin{array}{l}\text { other general production } \\
\text { expenses }\end{array}$ & 0 & 0 & 0 \\
\hline \multirow[t]{5}{*}{2.2 . } & $\begin{array}{l}\text { General operating } \\
\text { expenses for the project, } \\
\text { total }\end{array}$ & 0 & 0 & 0 \\
\hline & including: & & & \\
\hline & $\begin{array}{l}\text { costs of remuneration of } \\
\text { employees of the } \\
\text { management apparatus at } \\
\text { the level of workshops } \\
\text { and enterprises }\end{array}$ & 0 & 0 & 0 \\
\hline & insurance premiums & 0 & 0 & 0 \\
\hline & other expenses & 0 & 0 & 0 \\
\hline 3. & $\begin{array}{l}\text { Total costs for the } \\
\text { production and sale of all } \\
\text { types of products (works, } \\
\text { services) for the project, } \\
\text { total }\end{array}$ & 498438 & 498438 & 498438 \\
\hline
\end{tabular}

The composition of direct (variable) costs includes:

- direct material costs - 93.94 rubles / kg excluding VAT;

- labor costs for workers, employees and engineers;

-insurance premiums - 30\%;
- other direct - 3\% of the organization's proceeds from the project, excluding VAT (in this case, from savings).

Fixed costs are those costs that remain unchanged regardless of the dynamics of production and sales volumes.

The total (fixed) costs include (table 4):

- general production expenses for the project (depreciation; other overhead - taxes included in the cost);

- general business expenses for the project (costs of remuneration of employees of the administrative apparatus; insurance premiums - 30\%; other expenses $0 \%$ of the organization's proceeds from the project).

Drawing up a financial plan

Calculation of the amount of project financing by sources

Within the framework of this feasibility study, there is no need to finance capital investments for the project.

Calculations of the amounts of taxes and fees to the budget. Budget effect

The sum of all taxes and fees for this project under the general taxation system includes (table 5):

- VAT on sold products (work, services) - $10 \%$ (in accordance with subparagraph 1 of paragraph 2 of Article 164 of the Tax Code of the Russian Federation);

- income tax - $20 \%$.

Table 5. Calculation of taxes and fees for the project.

\begin{tabular}{|c|c|c|c|c|}
\hline \multirow[t]{2}{*}{ No. } & \multirow[t]{2}{*}{ Indicator } & \multicolumn{3}{|c|}{ Indicator value, rub } \\
\hline & & 2018 yr. & 2019 yr. & $2020 \mathrm{yr}$. \\
\hline \multirow[t]{4}{*}{1.} & Income tax & & & \\
\hline & taxable base & 167207 & 167207 & 167207 \\
\hline & tax rate & $20 \%$ & $20 \%$ & $20 \%$ \\
\hline & $\begin{array}{llll}\begin{array}{l}\text { amount } \\
\text { payable }\end{array} & \text { tax } & \text { (due) } \\
\end{array}$ & 33441 & 33441 & 33441 \\
\hline \multirow[t]{13}{*}{2.} & $\begin{array}{ll}\text { Value Added } & \text { Tax } \\
\text { (Investment) } & \end{array}$ & & & \\
\hline & taxable base & 0 & 0 & 0 \\
\hline & tax rate & $18 \%$ & $18 \%$ & $18 \%$ \\
\hline & $\begin{array}{l}\text { amount of tax (due) to be } \\
\text { refunded }\end{array}$ & 0 & 0 & 0 \\
\hline & $\begin{array}{lr}\text { Value added } & \text { tax } \\
\text { (reimbursement } & \text { of } \\
\text { current activities) } & \\
\end{array}$ & & & \\
\hline & taxable base & 478469 & 478469 & 478469 \\
\hline & tax rate & $10 \%$ & $10 \%$ & $10 \%$ \\
\hline & $\begin{array}{l}\text { amount of tax (due) to be } \\
\text { refunded }\end{array}$ & 47847 & 47847 & 47847 \\
\hline & $\begin{array}{l}\text { Value added tax (accrual } \\
\text { of current activities) }\end{array}$ & & & \\
\hline & taxable base & 665646 & 665646 & 665646 \\
\hline & tax rate & $10 \%$ & $10 \%$ & $10 \%$ \\
\hline & $\begin{array}{l}\text { amount of tax (due) to be } \\
\text { charged }\end{array}$ & 66565 & 66565 & 66565 \\
\hline & VAT payable & 18718 & 18718 & 18718 \\
\hline 3. & $\begin{array}{l}\text { Amount of taxes and } \\
\text { fees, total }\end{array}$ & 52159 & 52159 & 52159 \\
\hline
\end{tabular}


Cumulative budgetary effect from project implementation for the period from 2018 to 2020 will amount to 156,478 rubles.

Calculation of the plan of income and expenses of the project

The plan of income and expenses of the project includes:

- income from ordinary activities (net proceeds from the sale of main types of products (works, services);

- expenses for ordinary activities (total costs for the production and sale of all types of products (works, services) for the project, total).

After reaching the design capacity, the annual net profit of each next period will increase by more than 133 thousand rubles (table 6).

Table 6. Plan of income and expenses for the project for investors applying the general tax regime.

\begin{tabular}{|c|c|c|c|c|}
\hline \multirow{2}{*}{$\begin{array}{l}\mathrm{N} \\
\mathrm{o} .\end{array}$} & \multirow[t]{2}{*}{ Indicator } & \multicolumn{3}{|c|}{$\begin{array}{l}\text { Value of indicators, } \\
\text { thousand rubles }\end{array}$} \\
\hline & & $\begin{array}{c}2018 \\
\text { yr. }\end{array}$ & $2019 \mathrm{yr}$. & $2020 \mathrm{yr}$. \\
\hline \multirow[t]{14}{*}{1.} & $\begin{array}{l}\text { Income and expenses from } \\
\text { ordinary activities }\end{array}$ & & & \\
\hline & $\begin{array}{l}\text { Revenue (net) from the sale } \\
\text { of goods, products, works, } \\
\text { services }\end{array}$ & 665646 & 665646 & 665646 \\
\hline & $\begin{array}{l}\text { The total cost of goods sold, } \\
\text { products, works, services, } \\
\text { total }\end{array}$ & 498438 & 498438 & 498438 \\
\hline & including: & & & \\
\hline & material costs & 478469 & 478469 & 478469 \\
\hline & wages & 0 & 0 & 0 \\
\hline & insurance premiums & 0 & 0 & 0 \\
\hline & other costs & 19969 & 19969 & 19969 \\
\hline & Gross profit & 167207 & 167207 & 167207 \\
\hline & Gross profitability & $25,1 \%$ & $25,1 \%$ & $25,1 \%$ \\
\hline & $\begin{array}{l}\text { Selling and administrative } \\
\text { expenses }\end{array}$ & 0 & 0 & 0 \\
\hline & EBITDA & 167207 & 167207 & 167207 \\
\hline & depreciation deductions & 0 & 0 & 0 \\
\hline & EBIT & 167207 & 167207 & 167207 \\
\hline \multirow[t]{5}{*}{2.} & Other income and expenses & & & \\
\hline & Interest receivable & 0 & 0 & 0 \\
\hline & Percentage to be paid & 0 & 0 & 0 \\
\hline & Profit (loss) before tax & 167207 & 167207 & 167207 \\
\hline & Current income tax & 33441 & 33441 & 33441 \\
\hline \multirow[t]{2}{*}{3.} & $\begin{array}{l}\text { Net profit (loss) of the next } \\
\text { period }\end{array}$ & 133766 & 133766 & 133766 \\
\hline & Net return on sales & $20 \%$ & $20 \%$ & $20 \%$ \\
\hline
\end{tabular}

Calculation of the plan of cash receipts and payments

At each step, the value of the cash flow is characterized (table 7):

- an inflow equal to the amount of cash receipts (or results in value terms) at this step;

- outflow, equal to payments at this step;

- balance (active balance, effect) equal to the difference between inflow and outflow.

For cash flow from investment activities

- outflows include capital investments, commissioning costs, liquidation costs at the end of the project, costs of increasing working capital and funds invested in additional funds;

- to inflows - the sale of assets (possibly conditional) during and after the end of the project, receipts due to a decrease in working capital.

Table 7. Cash receipts and payments plan.

\begin{tabular}{|c|c|c|c|c|}
\hline \multirow[t]{2}{*}{ No. } & \multirow[t]{2}{*}{ Indicator } & \multicolumn{3}{|c|}{ Indicator value, rub } \\
\hline & & $\begin{array}{c}2018 \\
\text { yr. }\end{array}$ & \begin{tabular}{c|}
2019 \\
yr.
\end{tabular} & $\begin{array}{c}2020 \\
\text { vr. }\end{array}$ \\
\hline \multirow[t]{2}{*}{1.} & $\begin{array}{l}\text { Cash balance at the beginning } \\
\text { of the reporting period }\end{array}$ & 0 & 115048 & 230097 \\
\hline & \begin{tabular}{lll|} 
Cash flow from current \\
activities
\end{tabular} & & & \\
\hline 2. & $\begin{array}{l}\text { Cash received from buyers and } \\
\text { customers (including advances) }\end{array}$ & 665646 & 665646 & 665646 \\
\hline \multirow[t]{6}{*}{3.} & Funds directed to: & 550597 & 550597 & 550597 \\
\hline & $\begin{array}{l}\text { payment for purchased goods, } \\
\text { works, services, raw materials } \\
\text { and other current assets }\end{array}$ & 478469 & 478469 & 478469 \\
\hline & wages & 0 & 0 & 0 \\
\hline & payment of dividends, interest & 0 & 0 & 0 \\
\hline & calculations for taxes and fees & 52159 & 52159 & 52159 \\
\hline & other payments & 19969 & 19969 & 19969 \\
\hline \multirow[t]{2}{*}{4.} & $\begin{array}{ll}\text { Net cash from continuing } \\
\text { operations } \\
\text { paragraph 3) }\end{array}$ & 115048 & 115048 & 115048 \\
\hline & $\begin{array}{l}\text { Cash flows from investing } \\
\text { activities }\end{array}$ & & & \\
\hline 5. & Cash received & 0 & 0 & 0 \\
\hline \multirow[t]{4}{*}{6.} & Funds directed to: & 0 & 0 & 0 \\
\hline & $\begin{array}{l}\text { acquisition of fixed assets, } \\
\text { profitable investments in } \\
\text { tangible assets and intangible } \\
\text { assets }\end{array}$ & 0 & 0 & 0 \\
\hline & $\begin{array}{l}\text { purchase of securities and other } \\
\text { financial investments }\end{array}$ & 0 & 0 & 0 \\
\hline & other payment & 0 & 0 & 0 \\
\hline \multirow[t]{2}{*}{7.} & $\begin{array}{l}\text { Net cash from investing } \\
\text { activities (paragraph 5 - } \\
\text { paragraph 6) }\end{array}$ & 0 & 0 & 0 \\
\hline & $\begin{array}{lll}\text { Cash flows from financing } \\
\text { activities }\end{array}$ & & & \\
\hline \multirow[t]{3}{*}{8.} & Funds received from: & 0 & 0 & 0 \\
\hline & $\begin{array}{l}\text { contributions of founders to the } \\
\text { authorized capital }\end{array}$ & 0 & 0 & 0 \\
\hline & bank loans & 0 & 0 & 0 \\
\hline \multirow[t]{3}{*}{9.} & Funds directed to: & 0 & 0 & 0 \\
\hline & $\begin{array}{l}\text { repayment of loans and credits } \\
\text { (without interest) }\end{array}$ & 0 & 0 & 0 \\
\hline & other payments & 0 & 0 & 0 \\
\hline 10. & 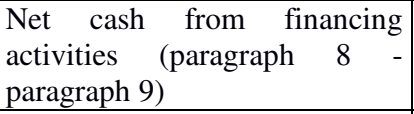 & 0 & 0 & 0 \\
\hline 11. & $\begin{array}{l}\text { Net increase (decrease) in cash } \\
\text { and cash equivalents } \\
\text { (paragraph } 3+\text { paragraph } 6+ \\
\text { paragraph 9) }\end{array}$ & 115048 & 115048 & 115048 \\
\hline 12. & $\begin{array}{l}\text { Cash balance at the end of the } \\
\text { reporting period }\end{array}$ & 115048 & 230097 & 345145 \\
\hline
\end{tabular}

A necessary condition for the feasibility of the project is a positive value of the cash flow indicator on a cumulative total for each time interval. 


\section{Analysis of project risks}

The analysis of project risks begins with their classification and identification, that is, with their qualitative description and definition - what types of risks are inherent in a particular project in a given environment under existing economic, political, legal conditions. As part of the implementation of the initiated project, there are the following risks:

Technological risk - readiness of the technology for use, serviceability and maintainability of equipment, availability of spare parts, additional equipment and devices, equipment with tools, training of service personnel, availability of qualified personnel (if provided for by the project), participation in the installation and training of foreign specialists.

Technological risk is low.

Organizational and managerial risk - availability and guarantee of implementation of the project schedule, responsibility of participants for noncompliance with the schedule, availability of qualified management personnel (certification of managers) and others.

Organizational and managerial risk is low.

Material and technical support risk - assessment of the possibility of switching to alternative raw materials, the level of incoming quality control of raw materials.

No logistics risk due to market specifics.

Financial risk - an assessment of the current financial position, the likelihood of non-payment by the project participants, credit and interest rate risks.

Financial risk is absent.

Economic risks - the stability of the applicant's economic position to changes in the macroeconomic situation in the country, assessment of the consequences of an increase in tariffs and prices for strategic resources, the possibility of reducing effective demand and prices for products in the Krasnodar Territory and the country as a whole, the presence of alternative sales markets, the consequences of a worsening tax climate.

Economic risks are medium.

Environmental risks - possible penalties and their impact on the economic situation of the applicant.

The environmental risks are low.

\section{Conclusion}

The essence of the proposed project and place of realization:

Within the framework of the initiated project, it is planned to launch the production of mayonnaise with chitosan and protein concentrate at the existing facilities of a public catering enterprise and replace it with industrial mayonnaise used at the enterprise.

Efficiency of project realization:

Since the project does not imply the realization of investments, the evaluation of the economic effects and economic efficiency of the project is given in terms of EBITDA, net profit (loss) for the next period, net profitability of sales (table 8 ).
Table 8. Evaluation of economic effects and economic efficiency of the project.

\begin{tabular}{|l|r|}
\hline \multicolumn{1}{|c|}{ Indicator name } & \multicolumn{1}{|c|}{ Indicator value } \\
\hline EBITDA & $167207 \mathrm{rub}$ \\
\hline Net profit (loss) of the regular period & $133766 \mathrm{rub}$ \\
\hline Net profitability of sales & $20 \%$ \\
\hline
\end{tabular}

Budgetary effect from project realization:

As a result of the realization of this investment project, the aggregate budgetary effect (the total amount of tax revenues to the budgets of all levels) for the period from 2018 yr. to 2020 yr. amounted to 156,478 rubles.

\section{References}

1. R. Bukhtoyarov, N. Bugayets, M. Tamova, I. Reutskaya Food technology. 5-6 (311-312), 1113 (2009).

2. O. Chugunova Scientific review. Economic sciences. 3, 29-39 (2017).

3. E. Podzharaya, V. Moiseeva Digital Science. 5 (5), 73-91 (2020).

4. T. Smotrina, O.Esenamanov, O. Stoyanov Bulletin of the Technological University. 9 (23), 34-37 (2020).

5. Z. Bukhtoyarova, I. Kulikov, N. Bugayets, O. Korneva Food technology. 1 (272), 84-85 (2003). 